\title{
The effect of chopped hay on feed intake, rate of eating and rumination of dairy cows
}

\author{
G. C. J. Voskuil and J. H. M. Metz \\ Department of Animal Husbandry, Agricultural University, Wageningen, \\ the Netherlands
}

Accepted: 5 May 1973

\section{Summary}

The effect of chopped hay on feed intake, eating rate and rumination time was studied. Relationships between these variables were evaluated. Ten pregnant cows at the end of lactation were each given $3 \mathrm{~kg}$ of concentrates daily and chopped or unchopped hay ad libitum.

No significant effect of chopping the hay on dry matter intake of hay and total ruminating time could be shown. However the duration of rumination per $\mathrm{kg}$ of hay consumed was lowered significantly when chopped hay was given. Chopping the hay a!so caused a significant reduction in the number of boli per day.

Daily hay intake proved to be positively correlated with duration of rumination. When unchopped hay was given, a higher eating rate was associated with a longer rumination time. When chopped hay was fed, no significant relationship between these parameters was found.

\section{Introduction}

Campling (1970) quotes numerous references to indicate that with diets consisting mainly of roughage, voluntary feed intake is limited by the capacity of the reticulorumen and by the rate of disappearance of digesta from this organ. The rate of disappearance of digesta depends on its rate of breakdown in the reticulo-rumen by both microbial and mechanical processes.

The present study deals with some aspects of the mechanical breakdown. An experiment was designed to study the effect of chopping the roughage on the feed intake, rate of eating and rumination. Also relationships between these variables were taken into consideration. Freer et al. (1962) demonstrated the existence of a complementary relationship between the mastication during eating an the rumination activity.

The various experiments in literature on the effect of chopping on feed intake do not give the same results. Duckworth \& Shirlaw (1958) found a lower dry matter intake when the silage was chopped, Keith et al. (1960), however, a higher intake. Slack et al. (1960) did not find any effect of chopping on hay intake.

In the experiments of Duckworth \& Shirlaw (1958) chopping of the roughage did not affect the duration of rumination per $\mathrm{kg}$ of dry matter. Also Kick et al. (1937) found no marked decrease in duration of rumination on chopped feed. In experiments with sheep Gordon (1958) even traced some increase in the duration of rumination 
when dried grass was chopped. The results of these kinds of experiments will be affected undoubtly by the size of the particles that result after chopping since grinding (strong reduction of particle size) markedly decreases the duration of rumination (Kick et al., 1937; Gordon, 1958; Pearce \& Moir, 1964; Campling \& Freer, 1966).

\section{Material and method}

Ten pregnant cows were used, five of the Meuse-Rhine-Yssel breed, four of the Dutch Friesian breed and one of the Groninger breed. They all were in the end phase of lactation. Two experimental groups (A and B) of five animals were made which were equal with respect to age, stage of pregnancy and milk production. Each animal was ted individually and received $3 \mathrm{~kg}$ of concentrates and hay ad libitum. Concentrates viere given at $06 \mathrm{~h} 00$ only. The animals left no residues. The daily ration of hay was divided equally into two portions given at $08 \mathrm{~h} 30$ and $18 \mathrm{~h} 00$. The total roughage supply was based on a daily residue of about $2 \mathrm{~kg}$ hay not consumed. The hay was fed to the animals in two physically different forms: unchopped (long) and chopped. In Fig. 1 the frequency distributions of the size of the particles in both types of hay are given. The average length of the long hay particles was $69.6 \mathrm{~mm}$ and of the chopped hay particles $13.6 \mathrm{~mm}$. The chemical composition and feeding value of the hay

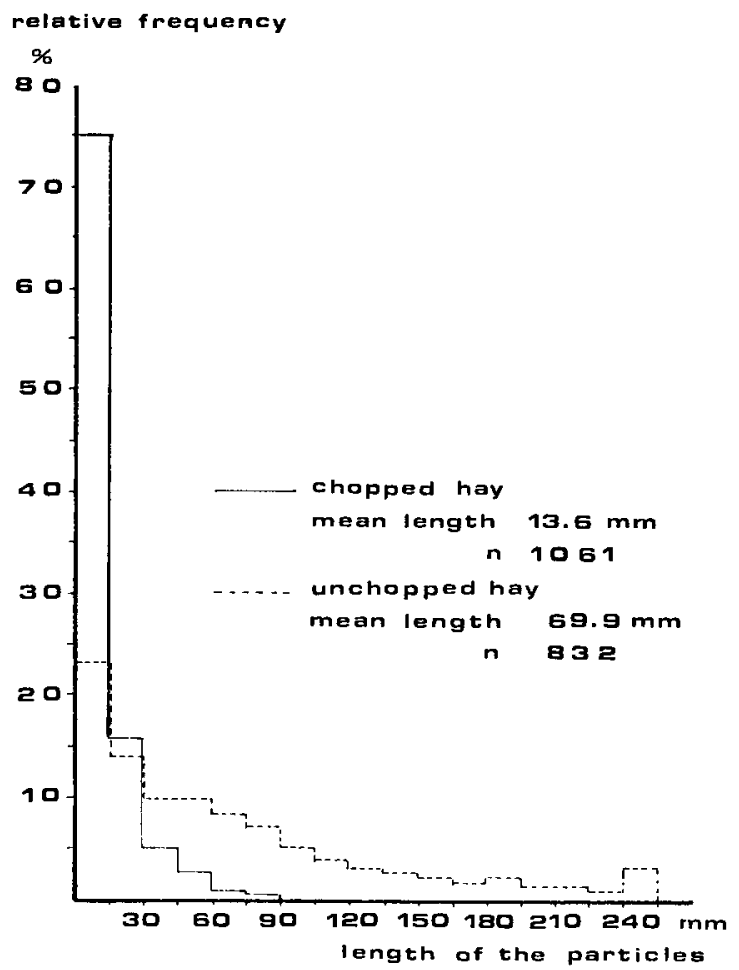

Fig. 1. Frequency distribution histograms of the length of the chopped and unchopped hay particles. 
Table 1. Chemical composition and feeding value of the experimental feeds.

\begin{tabular}{|c|c|c|c|c|c|c|}
\hline & \multirow{2}{*}{$\begin{array}{l}\text { Dry } \\
\text { matter } \\
(\%)\end{array}$} & \multicolumn{5}{|l|}{ In dry matter } \\
\hline & & $\begin{array}{l}\text { crude } \\
\text { protein }(\%)\end{array}$ & $\begin{array}{l}\text { crude } \\
\text { fibre }(\%)\end{array}$ & $\begin{array}{l}\text { ash } \\
(\%)\end{array}$ & $\begin{array}{l}\text { digestable } \\
\text { crude } \\
\text { protein }(\%)\end{array}$ & $\begin{array}{l}\text { starch } \\
\text { equivalents } \\
(\mathrm{g} / \mathrm{kg})\end{array}$ \\
\hline Unchopped hay & 86.0 & 12.2 & 27.3 & $\begin{array}{l}12.3 \text { (incl. } 3.2 \% \\
\text { sand) }\end{array}$ & 7.3 & 440 \\
\hline Chopped hay & 85.5 & 13.0 & 28.5 & 9.7 (no sand) & 7.9 & 450 \\
\hline
\end{tabular}

are given in Table 1. During the chopping process the hay lost nearly all sand.

The lay-out of experiments is presented in Table 2. Both groups of animals received chopped and unchopped hay reciprocally. In the first part of the experiment group A received chopped hay and group B long hay. In the second part group A received long hay and group B chopped hay. Each period consisted of a preliminary period of 15 days and a main period of 5 days. During these five-day periods the daily hay intake was measured individually and the eating rate and the rumination behaviour were recorded. The eating rate was measured twice daily, i.e. during the first meal after the supply of hay at $08 \mathrm{~h} 30$, and again at $18 \mathrm{~h} 00$. A meal was considered to be ended when a non-feeding period of at least 10 minutes followed. The total duration of eating was calculated from the total length of the meal minus the total length of non-feeding intervals within the meal lasting for longer than 1 minute. The eating rate was expressed as the average amount of feed ingested per 5 minutes of eating.

The occurrence of rumination was registered by means of a 20-point Esterline Angus event recorder. For this purpose a leather headstall with an extra string under the underjaw was placed on the head of the animal. Between both strings a microswitch had been placed, which was connected with the recorder. Whenever the animal opened its mouth the underjaw pressed the button of the microswitch, causing a signal. Because of the very characteristic registration pattern it was easy to make differentiation on the recorder chart between rumination and eating or other behaviour which was accompanied with jaw movements (e.g. grooming) (see Fig. 2). With a chart speed of 75 $\mathrm{cm} / \mathrm{h}$ the separate rumination cycles could be distinguished on the chart very clearly. Based on the recorded signals the total duration of rumination and the number of boli (cycles) per day were calculated. During the second part of the experiments about half of the recorded data of one animal were lost because of a defect microswitch. The missing values have been estimated and inserted.

Table 2. Lay-out of the experiment

\begin{tabular}{lrlll}
\hline $\begin{array}{l}\text { Subsequent phases } \\
\text { in the experiment }\end{array}$ & $\begin{array}{l}\text { Number } \\
\text { of days }\end{array}$ & \multicolumn{2}{l}{ Type of hay } \\
\cline { 3 - 4 } & & group A & group B \\
Preliminary period & 15 & chopped & long \\
Main period & 5 & chopped & long \\
Preliminary period & 15 & long & chopped \\
Main period & 5 & long & chopped \\
\hline
\end{tabular}




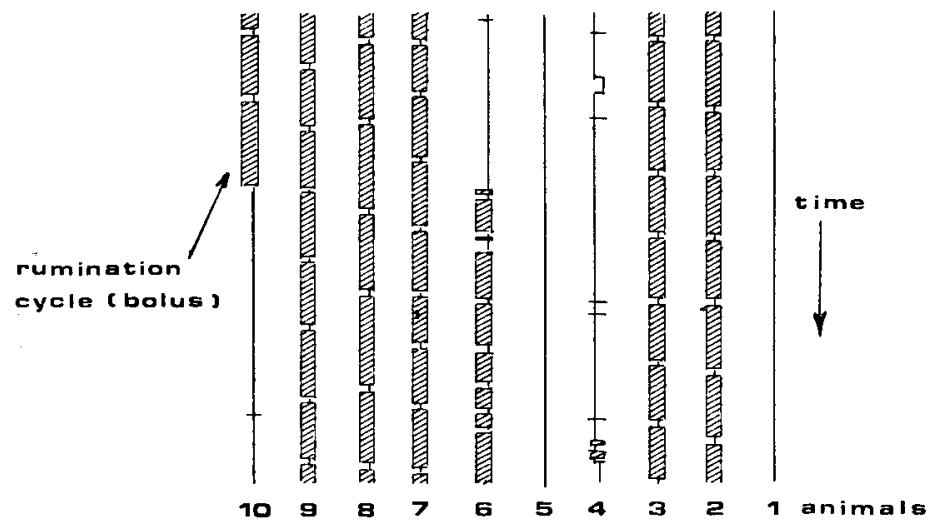

Fig. 2. Detail of a recorder chart, demonstrating rumination behaviour. Six animals show rumination hehavious: 2, 3, 7, 8, 9 and 10. Every closed block corresponds with one rumination cycle. Animal 6 shows feeding behaviour (irregular registration pattern); 1,4 and 5 are neither ruminating nor eating.

\section{Results}

The average values and standard deviations of hay intake, eating rate, duration of rumination and number of boli are presented in Table 3. In both groups of animals and on both types of hay the eating rate in the evening was higher than in the morning. The eating rate for long hay was calculated from $92 \%$ of the total daily feed intake.

Táble 3. The average values and standard deviations of hay intake, eating rate, duration of rumination and number of boli per day for both groups of animals and both types of hay.

\begin{tabular}{|c|c|c|c|}
\hline \multicolumn{2}{|l|}{ Group A } & \multicolumn{2}{|l|}{ Group B } \\
\hline long hay & shopped hay & long hay & chopped hay \\
\hline$s_{x}$ & $s_{x}$ & $s_{x}$ & $s_{\mathbf{x}}$ \\
\hline
\end{tabular}

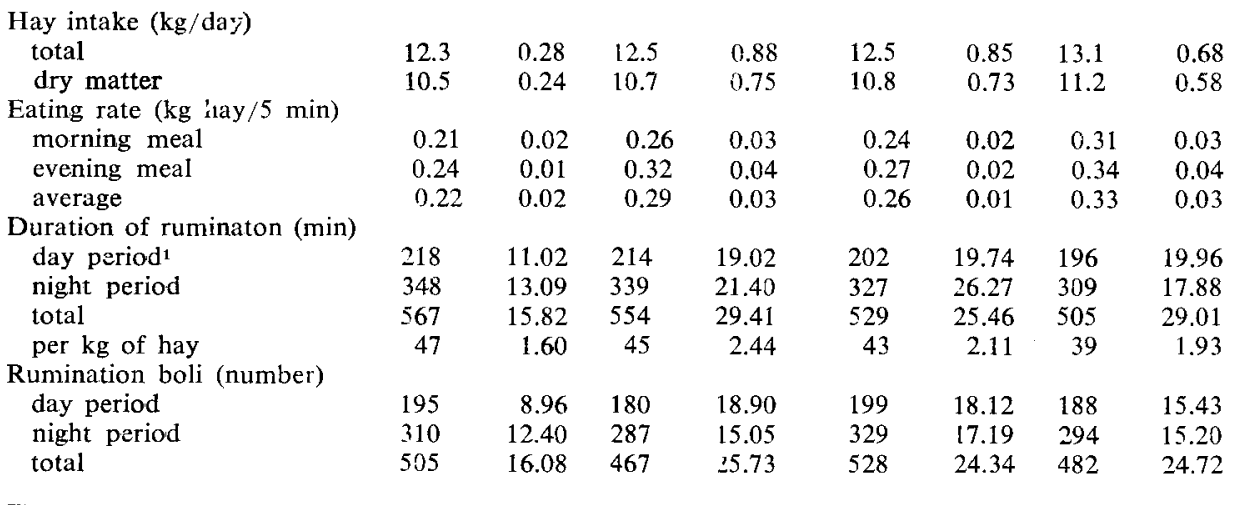

$\mathrm{s}_{\mathrm{x}}=$ standard deviation within animals.

: The day period is from $08 \mathrm{~h} 30$ to $18 \mathrm{~h} 00$. 
Table 4. The relative influence of experimental period, group of animals and type of hay on hay intake, eating rate and rumination. The values in the table are percentages of the total variances caused by each of these factors.

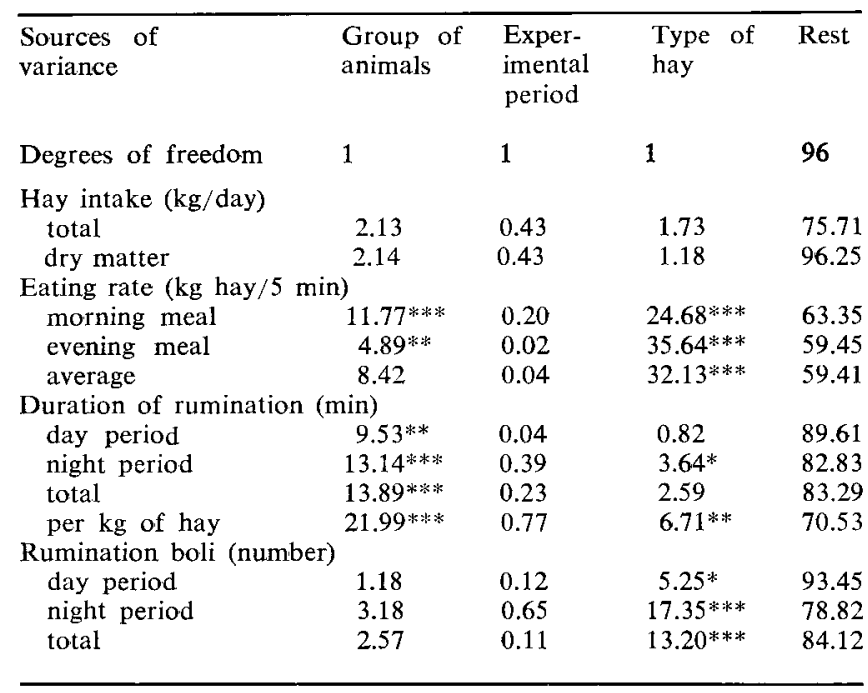

$* \mathrm{P}<0.05$; ** $\mathrm{P}<0.01$; *** $\mathrm{P}<0.001$.

For chopped hay this value was $87 \%$. As a result most hay was eaten during both meals just after the supply of fresh feed. The average length of the meals with long hay was 122 minutes and with chopped hay 94 minutes. During the day (from $08 \mathrm{~h} 30$ to $18 \mathrm{~h} 00$ ) there was less rumination activity than during the night (from $18 \mathrm{~h} 00$ to $08 \mathrm{~h} 30$ ). However during the night the mean duration of rumination per hour was only 1 minute more than during the day.

Three effects were tested by means of an analysis of variance: the effect of groups, the effect of the experimental period and the effect of chopping the hay. In Table 4 the relative effects and the testing results are given. The effect of the experimental period was small and not significant. Between the groups of animals there was only a significant difference in total duration of rumination and eating rate. In the other parameters no significant differences were found. By chopping the hay both the daily hay intake and the total duration of rumination were not affected significantly. However chopping reduced the mean duration of rumination per $\mathrm{kg}$ of hay eaten and the number of boli significantly. On the other hand the eating rate was significantly raised by chopping.

For both types of hay the mean correlation coefficients for the whole group of animals were calculated between the different variables (Table 5). A significant positive correlation between hay intake and duration of rumination could be traced. With unchopped hay there was no significant correlation between eating rate and hay intake and between eating rate and rumination activity. For the chopped hay these relationships were negatively significant however.

To eliminate effects of twisting of the variables also partial correlation coefficients were calculated. For unchopped hay the partial correlation coefficient between hay 
Table 5. Mean correlation coefficients between hay intake, eating rate and rumination activity, calculated per type of hay for the whole group of animals.

\begin{tabular}{|c|c|c|}
\hline Variables & $\begin{array}{l}\text { Long } \\
\text { hay }\end{array}$ & $\begin{array}{l}\text { Chopped } \\
\text { hay }\end{array}$ \\
\hline Hay intake $\times$ duration of rumination & $+0.59 * *$ & $+0.63 * *$ \\
\hline Hay intake $\times$ number of boli & $+0.58^{* *}$ & $+0.55 * *$ \\
\hline Hay intake $\times$ eating rate & +0.03 & $-0.47 * *$ \\
\hline Eating rate $x$ duration of rumination & +0.21 & $-0.36^{*}$ \\
\hline Eating rate $\times$ number of boli & +0.18 & $-0.38 *$ \\
\hline Duration of rumination $x$ number of boli & $+0.88^{* *}$ & $+0.91 * *$ \\
\hline
\end{tabular}

$* \mathrm{P}<0.05 ; * * \mathrm{P}<0.01$.

intake and duration of rumination without the effect of eating rate was calculated as $+0.60(\mathrm{P}<0.01)$ and for chopped hay as $+0.56(\mathrm{P}<0.01)$. With a constant feed intake the partial correlation coefficient between duration of rumination and eating rate was $+0.29(\mathrm{P}<0.05)$ on unchopped and $-0.09(\mathrm{P}>0.05)$ on chopped hay.

\section{Discussion}

In this experiment reduction of the particle size of the roughage by chopping had a small effect on the daily feed intake (see Tables 3 and 4). In an experiment with 12 cows Slack et al. (1960) also did not find any effect of chopping on feed intake. Accepting the theory about the physical control of food intake (Campling, 1970) we must conclude that the reduction of the particle size of the roughage by chopping had no clear effect on the rate of disappearance of the food from the reticulo-rumen.

Chopping causes a strong increase of eating rate. The calculated eating rates in these experiments were based on about $90 \%$ of the total daily intake. Therefore the obtained values are to be considered representative for the average eating rate. Suzuki et al. (1969) measured the eating rate with more or less the same methods. For normal long hay they found somewhat higher eating rates $(0.30-0.48 \mathrm{~kg}$ per $5 \mathrm{~min})$ than we did $(0.22-0.26 \mathrm{~kg}$ per $5 \mathrm{~min})$, but they did not apply ad libitum feeding strictly. From the experiments of Freer et al. (1962) and Gill et al. (1966) it can be concluded that a higher eating rate is associated with less mastication during eating per weight unit of feed. The higher eating rate on the chopped hay can be explained because less mastication is necessary before swallowing. On the other hand, when the unchopped hay is masticated more than the chopped hay during eating, the difference between both types of feed will be less when they arrive in the reticulo-rumen. This agrees with the fact that chopping has only a small effect on the rumination (see Tables 3 and 4). On an average the duration of rumination per $\mathrm{kg}$ of hay decreased by only 3 minutes ( 7 à $8 \%$ ) by chopping. The number of boli per day decreased accordingly. These results are in agreement with the experiments of Kick et al. (1937) and Duckworth \& Shirlaw (1958). In addition, Duckworth \& Shirlaw found an increase of the duration of the rumination cycles by chopping. In our experiments too the rumination cycles were longer for the chopped feed. The causes of the phenomenon are not yet clear.

There was a strong positive correlation between the rumination time per day and the total number of boli and also between these variables and the hay intake (Table 5). 
This supports the finding of Freer et al. (1962) who concluded that the rumination time per weight unit of feed is rather independent of the total intake.

The relationship between hay intake and eating rate was different for both types of hay. For long hay there was no significant correlation. However for chopped hay a negative correlation was found. To explain these differences perhaps the experiment of Foeken (pers. commun., 1971) has to be mentioned. Foeken studied the course of eating rate during the intake of coarse and small pellets of concentrates. In the beginning of a feeding period the eating rate of small pellets was higher than that of coarse feed. However during the feeding period the eating rate decreased faster for small pellets than for coarse pellets. It is likely that for chopped hay the cows eat according to the same pattern as for small pellets. If we assume that the eating rate rapidly decreases during a meal with chopped hay, a higher intake of this hay (longer duration of eating) is then associated with a lower mean eating rate. The eating rate of unchopped hay should remain on a more constant level.

Naturally the relationship between eating rate and duration of rumination depends on the correlations between each of these variables and the feed intake. Therefore partial correlation coefficients were calculated. For the ration with unchopped hay the eating rate and duration of rumination were positively correlated $(\mathrm{r}=+0.29$; $\mathbf{P}<0.05$ ). Also Freer et al. (1962) found such a positive relationship between eating rate and duration of rumination. However in their experiments a higher eating rate was obtained by restricting the feeding time and not by natural variation in the eating rate under ad libitum conditions as in our experiment. For the chopped hay there did not exist a significant correlation between eating rate and duration of rumination $(r=$ $-0.09 ; \mathbf{P}>0.05$ ). Less mastication is necessary for eating hay of this type. Presumably variation in the eating rate (intensity of mastication) of the chopped hay will have a small effect on the particle size of the swallowed feed. This presumption may explain the fact that no relationship between eating rate and duration of rumination was found.

\section{References}

Campling, R. C., 1970. Physical regulation of voluntary intake. In: A. T. Phillipson (Ed.) Pitysiology of digestion and metabolism in the ruminant. Oriel Press, New Castle upon Tyne, England.

Campling, R. C. \& M. Freer, 1966. Factors affecting the voluntary intake of food by cows. 8. Experiments with ground, pelleted roughages. Br. J. Nutr. 26: 229-244.

Duckworth, J. E. \& D. W. Shirlaw, 1958. A study of factors affecting feed intake and the eating behaviour. Anim. Behav. 6: 147-154.

Freer, M., R. C. Campling \& C. C. Balch, 1962. Factors affecting the voluntary intake of food by cows. 4. The behaviour and reticular motility of cows receiving diets of hay, oat straw and oat straw with urea. Br. J. Nutr. 16: 279-295.

Gill, J., R. C. Campling \& D. R. Westgarth, 1966. A study of chewing during eating in the cow. Br. J. Nutr. 20: 13-23.

Gordon, J. G., 1958. The relationship between fineness of grinding of food and rumination. J. agric. Sci. 51: $78-80$.

Keith, J. M., W. A. Hardison, J. T. Huber \& G. C. Graf, 1961. The effect of the fysical form and the nutritive value of hay fed to lactating cows. J. Dairy Sci. 44: 1174.

Kick, C. H., P. Gerlaugh, A. F. Schalk \& E. A. Silver, 1937. The effect of mechanical processing of feeds on the mastication and rumination of steers. J. agric. Res. 55: 587-597.

Pearce, G. R. \& R. J. Moir, 1964. Rumination in sheep. 1. The influence of rumination and grinding upon the passage and digestion of food. Aust. J. agric. Res. 15: 635-644.

Slack, S. T., W. K. Kennedy, K. L. Turk \& O. A. Boyce, 1960. Effects of chopping on feeding value of hays. Bull. Cornell agric. Exp. Stn 950.

Suzuki, S., H. Fujita \& Y. Shinde, 1969. Change in the rate of eating during a meal and the effect of the interval between meals on the rate at which cows eat roughages. Anim. Prod. 11: 29-41. 